IJLRES - International Journal on Language, Research and Education Studies

ISSN: 2580-6777 (p); 2580-6785 (e)

Vol. 1, No. 2, 2017

Page: 240 - 255

\title{
COMMUNICATION TECHNIQUE OF HIZBUT TAHRIR INDONESIA (HTI) IN THE DEVELOPMENT OF CADRE IN NORTH SUMATERA
}

\author{
Rubino \\ rubino@gmail.com \\ School of Post Graduate, State Islamic University of North Sumatra, Indonesia \\ Mohd.Hatta \\ mohammadhatta@uinsu.ac.id \\ State Islamic University of North Sumatra, Indonesia \\ Abdullah \\ abdullahshah@uinsu.ac.id \\ State Islamic University of North Sumtra, Indonesia
}

\begin{abstract}
This study aimed to analyze the communication techniques applied Hizbut Tahrir Indonesia (HTI) in the development of cadres in North Sumatra. The approach used in this research is qualitative approach, with reason to understand the problem in its natural setting, and interpret this phenomenon based on the meaning given by the informant, also because this research is multidimensional which is the result of various situation complexity, so it needs to be analyzed the context around it. The informant of this research is determined by purposive technique that is explored based on the purpose of this research, with informant plan amounted to 6 (six) people that is 1 (one) management and 5 (five) person responsible lajnah. Based on the data obtained, the results of this study are, there are three communication techniques applied by the HTI in cadre development activities are: (1) informative techniques, namely by providing information about HTI and the main ideas it develops, to all levels of society both students, students, scholars, intellectuals, as well as influential figures in society such as government leaders, legislators, leaders of mass organizations, leaders of political parties, etc., as well as members of the cadre at the general level of learning, general level, (2) persuasive techniques by inviting them to join and support HTI preaching through dialogue, discussion, bulletin sharing, magazines, etc., and (3) the technique of human relationships by giving advice inter-personal to the community or members experiencing problems through consultation activities
\end{abstract}

Key Words: Communication Technique, Hizbut Tahrir Indonesia, The Development of Cadre.

\section{INTRODUCTION}

Communication is a basic human activity. Watzlamick, Beavin and Jackson as quoted by Sham, said "We can not not communicate". ${ }^{1}$ The point of their statement is that people can not escape from communicating activities, wherever they are at home, in the marketplace, in the office and as they still have to communicate. Since man was

1 Nina W. Syam. (2011). Psikologi Sebagai Akar Ilmu Komunikasi, Bandung: Simbiosa Rekatama Media. Page 35. 
created as a social being, then he can not escape from the activities of communicating. For communication is a process in which individuals relate to others in groups, organizations, and society.

According to Al-Maragi that the word Al Bisyarah means is to give news or information that is encouraging. ${ }^{2}$ Liliweri states that there are generally four main categories of communication functions: (1) information function, (2) instructional function, (3) persuasive function, and (4) entertaining function. If the four main functions are expanded, then two other functions will be found: (1) personal functions, which serve to express social identity, social integration, cognitive, and escape or solutions, (2) social functions, connect or bridge, socialize, and entertain. ${ }^{3}$

Based on the above opinion then the human communication is basically the goal is that there is a change in human beings. According to Effendy, there are at least four changes that are expected to occur in human beings as the purpose of the communication process: (1) attitude change, (2) change of opinion, (3) behavior change, and (4) social change). ${ }^{4}$

In an effort to realize the purpose of communication as the above opinion, the process of human communication can not be done haphazardly, but must use appropriate communication techniques in accordance with the objectives to be achieved. Related to that, according to Onong Uchjana Effendy there are at least four communication techniques that can be used are: (1) informative communication techniques, (2) persuasive communication techniques, (3) instructional communication techniques / coercive and (4) human communication techniques relation. ${ }^{5}$

Informative communication technique is a technique of delivering a message by providing information to the communicant for the communicant understand or understand about the message, so that will increasingly increase knowledge and understanding after getting the message. Meanwhile, persuasive communication techniques is a technique of delivering messages by influencing or persuading communicant to change attitudes, opinions, and behavior. Furthermore, instructive

2 Ahmad Mustafa Al-Maragi (1982). TafsirAl-Maragi, terj. Bahrun Abubakar dkk Semarang: Toha Putra. Page 110.

${ }^{3}$ Alo Liliweri. (2011). Komunikasi Serba Ada Serba Makna. Jakarta: Kencana. Page 138.

${ }^{4}$ Onong Uchjana Effendy. (2006). Ilmu Komunikasi Teori dan Praktek (Bandung: Remaja Rosdakarya, 2006), Page 8.

5 Ibid. Page 4 
Communication Technique of Hizbut Tahrir Indonesia (HTI) in the Development of Cadre in North Sumatera

communication techniques / coercive communication is the delivery of communication messages by giving instructions, pressure, and even coercion to the communicant that they want to change. While the communication technique of human relations is a technique of delivering messages by way of relationships among fellow human beings, in order to change the self communicant.

The four communication techniques above, certainly has its own ways in its application. Informative communication techniques, has a variety of ways for information submitted to the audience understood or understood by them both verbally and nonverbally such as through lectures or speeches, writings in the print media and so forth. Persuasive communication techniques, too, have a variety of ways both verbally and nonverbally, so that the audience is affected and persuaded so that they want to change. Likewise, coercive communication techniques have a variety of ways both verbally and nonverbally, in order for audiences to change. Likewise with the communication techniques of human relations, also has a variety of ways for the audience to experience changes both cognitive (knowledge), affective (attitude), and behavioral (behavior).

Application of communication techniques in the communication process above is very important both in interpersonal communication, group communication, as well as mass communication, both communications conducted by individual communicators as well as communications conducted by communicators collectively such as communications conducted by organizational groups both political organizations and social organizations, including religious mass organizations.

Implementation of communication techniques by religious mass organizations group in essence its purpose for communication process and socialization of vision, mission, and program of organization both to society and also to the cadres will run effectively. Implementation of communication techniques and communication process aimed at the cadres of the goal so that the cadres become militant cadres.

The phenomenon shows not a few religious mass organizations and political parties whose cadres are not militants, whereas they always communicate and socialize their vision, mission and program. But on the contrary, not least also religious mass organizations and political parties whose cadres become militant cadres who are fighting for their organizations. 
One of the mass religious organizations that have militant cadres is Hizbut Tahrir Indonesia (HTI) ${ }^{6}$. According to Syamsu Rizal HTI is one group of transnational Islamic movements that clearly shows its transnational character and shows significant development. The movement, founded by Taqiyuddin an-Nabhani, has branches of more than 40 countries and develops more freely in democratic countries. The main agenda of its transnational character is the establishment of the Khilafah, a system of global Islamic government under the rule of a caliph.7

The HTI name was officially used in May 2000, when an international conference on khilafah was held at the indoor tennis courts of Jakarta's senayan stadium. Although actually in the early 1980s ideas about Hizb ut-Tahrir is already there is through the contact with the Hizb ut-Tahrir community from the Middle East, especially with Al-Baghdadi. ${ }^{8}$

Since 2000 the HTI has been growing rapidly. The rapid development of HTI can be seen from the quantity of its members and the intensity of HTI activities in the public space, namely in the form of parades, seminars, dialogues, public discussions and media proliferation in various regions in the country. Even HTI branches have been spread in almost all provinces in Indonesia, including in Papua. Meanwhile, in North Sumatra organisationally HTI also stood in 2000 and its development is quite rapid, especially in various universities in North Sumatra. Many of the students and college students join this HTI group, even they become militant cadres who try to fight for the vision, mission, and program of HTI.

The rapid development of HTI as mentioned above, deserves the attention of researchers for the following reasons: First, HTI is part of a global Islamic movement that imports its ideology from the Middle East and has a political agenda that is to uphold the caliphate. By promoting Islam as a perfect ideology, HTI does not hesitate to reject ideologies such as communism, pluralism, secularism, nationalism, and even democracy. In Indonesia, including in North Sumatra, the model of Islamic

${ }^{6}$ HTI groups more represent themselves as political parties based on Islamic ideology than religious mass organizations. See Ahmad Syafi'i Mufid (Ed). Development of Transnational Religious Understanding in Indonesia (Jakarta: Research and Development Agency of the Ministry of Religion Religious Research and Development Center, 2011), Page 34.

7 Syamsu Rizal. Jaringan Hizbut Tahrir di Kota Makassar Sulawesi Selatan. in Ahmad Syafi'i Mufid (Ed). Perkembangan Paham Keagamaan Transnasional di Indonesia (Jakarta: Badan Litbang dan Diklat Puslitbang Kehidupan Keagamaan Kementerian Agama RI, 2011), Page 4.

8 Ibid, Page 22. 
applications like this, clearly something new, foreign, and different from the majority of Muslims. Although different from the majority of Muslims, but still get support from Muslims in North Sumatra. Second, unlike local Islamic organizations in North Sumatra, HTI does not struggle in party politics, but it has attracted many members of Muslim youth in North Sumatra. HTI is able to coach its cadres, thus becoming a militant cadre.

Based on the above two reasons, according to the analysis of the researchers, of course it can not be separated from the application of North Sumatra HTI communication techniques in the communication process it builds in conducting guidance to its cadres. But until now not yet known exactly about the communication techniques applied HTI North Sumatra in conducting guidance to his cadres. Therefore here the author feels it is important to conduct research related to: "Communication Technique Hizbut Tahrir Indonesia (HTI) in the Development of Cadres in North Sumatra". This research is important to be used as a model in the application of communication techniques, especially in the activity of cadre building in an organization.

\section{LITERATURE REVIEW}

Technique in language interpreted by method or system doing something. So communication techniques in language, can be interpreted by the method of delivering a message by someone to others, to notify or change attitudes, opinions, or behavior, either directly orally, or indirectly through the media.

In the process of communication, the determination and use of appropriate communication techniques is something that is very important and very supportive of communication goals. Mistakes in choosing and using communication techniques, it will greatly affect the results to be achieved from the communication process. Therefore, a communicator is required to be observant in choosing and using communication techniques in the process komunikasinya.

According to Onong Uchjana Effendy, there are at least four communication techniques that can be used in the communication process: (1) informative communication techniques, (2) persuasive communication techniques, (3) instructional / coercive communication techniques, and (4). For more details, the following will be presented: 


\section{a. Informative communication Technique}

Informative communication technique is a technique in communication whose purpose is to provide information or communicate to the communicant about an idea, idea or idea, so that the communicant knows and understands the idea, idea or idea. According to Alo Liliweri, informative communication is often called informative speeking which is the same kind of speech as a teacher teaches the students or an expert gives a public lecture. ${ }^{9}$ Like a teacher, the communicator begins to explain the existence of a concept, such as the concept of "the effectiveness of interpersonal communication". Communicators will provide information or explain why the public needs effective communication, communicators provide examples and demonstrations, he also convey the elements of effective communication, effective communication principles, some theories of communication effectiveness, supporting factors and inhibit the effectiveness of communication, and lastly make a conclusion and provide a definition of communication effectiveness.

Thomas Mann said that speech or convey information shows human civilization, because from speech, the public can know the breadth and depth of information a speaker has. There are three purposes of speech with Informative communication techniques are to: (1) entertain, (2) inform, and (3) persuasive. There are also other goals such as reviving inspiration or motivating the public to change attitudes. ${ }^{10}$

The application of informative communication techniques, can be done either verbally orally or in writing such as lectures, discussions, in the form of articles, bulletins, and so forth, as well as non-verbally as in the form of pictures, cues, and so forth. Can also be done using media or without media.

\section{b. Persuasive communication technique}

Persuasive communication techniques are communication tools, which are purposeful to change attitudes, opinions, and behaviors. Therefore, this technique of communication is more difficult. If the communication technique is informative the purpose is simply to notify, while persuasive communication techniques aim to change attitudes and behavior. If informative communication techniques impact only cognitive

\footnotetext{
${ }^{9}$ Liliweri. Komunikasi Serba.... Page 273

${ }^{10} \mathrm{Ibid}$, Page 274
} 
impact, but persuasive communication techniques impact include cognitive, affective, and behavioral impacts.

In order for persuasive communication to achieve its goals and objectives, it is necessary to carry out careful planning. Planning is done based on the components of communication process ie communicator, message, media, and communicant. For communicators, a message to be communicated in addition to the obvious contents, also must be managed properly. Messages should be organized according to self communicant who will be targeted. If the communicant to be targeted is clear, and the media has been set, then the message will be easy to set.

\section{c. Coersive communication technique}

Coercive communication techniques can be interpreted as a technique of pressing and forcing and instruction. This technique explains that person or group to change attitudes, opinions, and behaviors, the communicator / persuader will send a message by pressing, forcing, or giving instruction even with "brainwashing" tactics. ${ }^{11}$ In the various psychological literature on communications psychology, this coercive is often depicted on the possible use of coercive power by pressing, coercing, committing acts of violence, intimidation, and brainwashing programs. This coercive behavior, making people who have the power to freely control the people who are under his control.

This coercive technique, indeed rely on the power of a communicator. Because power is a person's ability to influence others so that he likes or dislikes to receive all messages sent for the achievement of intent and purpose desired komunikator / persuader. Indeed, although power is not necessarily a characteristic of the individual communicator / persuader, but this power explains the advantages and advantages of a persuader's position in the polarization of social relations in the midst of a society

\section{d. Human relation Technique}

In human relations activities, there are ways or techniques that can be used to help humans, who are frustrated by the problems they face, what is called counseling. The purpose of counseling is to help an individual who is facing a problem or suffering

${ }^{11}$ Liliweri. Komunikasi Serba.....Page 300. 
from frustration, to solve his or her own problems or to seek an atmosphere that creates courage to solve the problem.

Onong Uchjana Effendy states that in the human relations activities there are two types of counseling as communication techniques that can be used to assist a person in overcoming the problem, namely first, directional directive couseling, sometimes called counselor centered approach (counseling centered on counseling, and sometimes counseling, sometimes called counselee centered. ${ }^{12}$

\section{METHODOLOGY}

This research was a research in order to expose or reveal facts that occur in the field especially the facts related to communication techniques conducted HTI North Sumatra in cadre coaching. Therefore, the approach in this study is a qualitative research approach with emphasis on naturalistic analysis of the phenomena studied. This research was conducted in Hizbut Tahrir Indonesia (HTI) organization of North Sumatera or in the Regional Leadership Council of Tk.I (DPD I) of North Sumatra with the research informant, the board and the people who were given the mandate to conduct cadre training. In determining informant of this research, researcher use purposive technique, that is researcher determine characteristic of informant according to purpose of this research. The characteristics of informants are those who understand the process of guidance to the cadres, also those who are directly involved in the process of cadre development. To obtain the data, the researcher uses the Indepth interview technique that the researcher will interview in-depth the research informants related to the problem of this research. In addition, to support the results of interviews, researchers also use the technique of observation that researchers do direct observation of the implementation process of HTI communication techniques. In addition, the researchers also dig the data through documents that exist on HTI North Sumatra in the form of books, bulletins, or other documents that have something to do with this research.

12 Ibid. Page 142-143. 
Communication Technique of Hizbut Tahrir Indonesia (HTI) in the Development of Cadre in North Sumatera

\section{FINDINGS}

Associated with cadre coaching, each organization has its own cadre system, both the way and the material of its cadre. Likewise with HTI North Sumatra, it has its own stages, rules and materials in coaching those who want to join HTI.

Based on the results of research to be a member of HTI, then anyone should follow and pass four levels of coaching or cadre namely:

\section{a. General Studies Level.}

This level of public recitation is the first stage of the process of coaching or cadre in HTI. This level is followed by those newly joined by HTI. The duration of this coaching is for two months or eight meetings, with two hours in each meeting. At this level which is demanded from the congregation is the discipline in following the coaching. For those who are not disciplined then he can not go up to the next level which is the general level of halal.

Coaching at this level essentially invites pilgrims to do good deeds of virtue, understanding their duties and responsibilities as a Muslim. maintain aqeedah, and apply the laws of life ". Therefore, at the level of this public lecture the participants will be given information or messages about Islam especially regarding ihsanul charity or charitable deeds, concerning the duties and responsibilities of humans, aqidah, and syari 's legal matters.

Meanwhile, the technique applied by the musyrif in the delivery of the message that is by conducting public lecture in front of the pilgrims. At the lecture, the messages conveyed were supported by the arguments of both the Qur'an and the hadith. In addition, it is often conveyed to the virtues and threats or dangers of things such as the virtue of doing good deeds and threats to those who leave them

\section{b. General 'Halaqoh' Level.}

This general 'Halaqoh' level was the second level of the process of coaching or cadre in HTI. This level is followed by those who have already passed on the general level of study. The duration of this coaching is a minimum of two months or eight meetings, with two hours in each meeting. At this level, the number of participants is only a maximum of 5 people, and they are required to be more disciplined again in following the coaching. For those who are not disciplined then he can not go up to the next level of 'Halaqoh' which is the level of daris. 
Coaching at this level, basically invites participants to understand Islam more universally and comprehensively. Therefore, the material presented at this level of halalah is Islamic material that has fewer special studies such as: 1) Islam mabda, 2) siyasah Islam, 3) Knowing HTI that is the material about knowing HTI, basically invites coaching participants to understand about HTI as a political party that is ideology of Islam, its emergence background, its ideals, and its main ideas developed.

\section{c. 'Halaqoh' Level of Daris.}

'Halaqoh' level of daris s the third level of the process of coaching or cadre in HTI. This level is followed by those who have been graduated or completed at the general level of halal and can meet the specified customary requirements. Duration in coaching this level long enough can take years, because the study of a book to finish just sometimes the fastest 1 year. While the book should be studied in this level, at least 4 books.

'Halaqoh' in this level, the number of participants is also only a maximum of 5 people. At this level there are special conditions that must be fulfilled by the participants. If the participant can not meet the requirement then he / she can not follow the guidance at this level. The special conditions are: 1) If he is married, his wife must dress syar'i, 2) Participants are not involved in the issue of ribawi, 3) For those who are not married, then they are forbidden to do courtship.

In addition to these conditions, participants are also required to discipline following coaching conducted once a week for two hours, nor should be late more than 15 minutes each following coaching. Because for those who are unable to meet these requirements and not discipline in following coaching then he can not follow the guidance in the next level.

'Halaqoh' level of daris, it was already at the level of studying the books that become HTI's hold. The messages contained in the books are read and discussed together. Technique of delivering the message that is read by paragraph by paragraph, and discussed paragraph by paragraph also. The messages discussed have led to matters relating to the establishment of the Islamic caliphate. 
Communication Technique of Hizbut Tahrir Indonesia (HTI) in the Development of Cadre in North Sumatera

\section{d. 'Ha;aqoh' in the level of member.}

This member level coaching is the fourth or last level coaching. Coaching at this level, followed by those who have completed at the level of inheritance. This guidance is done by reviewing some books that have not been denied at the previous level. The coach in the coaching is carried out by fellow members who have reviewed the book that has been denied. The messages contained in the books are read interchangeably and then discussed together, especially by daris who have menghalakahkan book. The technique of delivering the message, similar to the technique at the previous level of coaching is the level of daris. Coaching at this level takes a long time, up to years.

In addition to guidance in the form of halakah and tasykib murokajah (guidance through the book) from house to house, HTI North Sumatra also perform guidance in the form of tasykib jama'i ie coaching of pilgrims in general.

The formation of pilgrims in general is done in the form of public recitation from house to house, in mosque or also in certain places that have been agreed together. In this general congregation building, the material presented is also general, but not apart from the concepts developed by HTI such as social problems, political issues, and so forth.

In addition, HTI also conducts personal guidance. This guidance is carried out to troubled HTI members while at the time of being coached either on the level of public prayer, the general level of pace, the level of daris or the level of the members. Or also those who are facing problems in their life whether personal, family, religion or economic problems and so on.

HTI members are problematic when in the process of coaching, for example members who are not disciplined in following coaching, or also members who violate the things that should not be done in the HTI when following the coaching. For the problem members, the coaching step is by calling them to the HTI office, then they will advise them.

As for members who are facing problems in their lives, usually they consult the musyrif and ask for suggestions and solutions to the problems that are facing it. This kind of coaching model is also done by HTI practitioners in the community. Ustadz Muhammad Fatih Al-Malawiy for example, as a boarding school boarder is often used as a place to ask the community about the religious issues they are facing. Likewise 
with ustadz Musa Abdul Gani, he is also often used as a place to consult by his congregation about the religious issues they are facing. ${ }^{13}$

\section{DISCUSSION}

Based on the above data, when discussed in more depth related to the communication techniques used HTI, in the process of coaching, the communication techniques applied HTI, namely:

\section{Informative Communication Technique.}

In conducting guidance of cadres, HTI North Sumatera applying informative communication techniques. The application of this technique is done by providing information to members of the cadre who are following the guidance related to Islam, also related to HTI and the main ideas that it developed.

Giving information to them is done both with verbal communication as well as nonverbal communication. Verbal communications that apply HTI North Sumatra in conducting cadres through verbal communication activities such as lectures, dialogues, discussions, and contact person. Also through written communication through bulletins, newspapers, tabloids, and magazines. While non-verbal communication applied by HTI in conducting cadre development is through the spread of non-verbal symbols such as bazaar activities, peaceful action activities, displaying HTI students with achievement, and so on.

The purpose of HTI communication using this informative communication technique, in essence for members of the cadre to have a universal and comprehensive understanding of Islamic teachings and concepts of Islamic teachings developed and applied HTI in life. With such understanding, they are expected to support the ideas and da'wah done by HTI.

\section{Persuasive Communication Technique.}

Persuasive communication technique is a communication technique by persuading and influencing communicant through the messages conveyed, with the

13 Syaiful Rahman, Vice Chairman of DPD HTI North Sumatra, interview in Medan, October 7, 2016 
aim that communicant can change attitude, opinion, and behavior in accordance with the messages received.

In the context of cadre development, HTI North Sumatra applied persuasive communication techniques. The application of this technique is done by influencing the attitude, opinion and behavior of the cadre members, through the activities of da'wah and giving information related to Islam, also related to HTI and the main ideas that it develops, by revealing the arguments that are sourced from the Qur'an and Sunnah Rasulullah Saw.

Factors of concern to HTI North Sumatra, for the successful implementation of persuasive communication techniques and achieve the goal as stted in the following:

a. Target characteristics factor (communicant). In conducting guidance of the cadres, so that the people being constructed are fully bersersuasif, HTI North Sumatra is very consider the characteristics of people who will be given information, which will be invited, and who will do coaching. Therefore, in the process of implementing cadre development, the division is based on the level of general level of teaching, general level, level of daris, and level of members.

b. Factor source characteristics (communicators). In the process of guidance of cadres, and for them to be tersersuasif, HTI North Sumatra also consider the characteristics of communication sources such as level of education, expertise, professionalism and functional, or ability and communication skills, or may also display the personality of someone who became a source of communication. In the process of coaching, HTI considers the characteristics of the person who becomes musyrif. For example, people who are allowed to provide minimal coaching for those who have completed the leveling training.

c. Message characteristics. In the process of cadre development, so that they are tersersuasif, then HTI North Sumatra also consider the characteristics of the message delivered. In the cadre coaching process, the messages are prepared according to their respective coaching levels.

d. Characteristics of ariqah (method). In the process of cadre development, so that they are terpersuasi, HTI Sumut also consider the characteristics of ariqah. In the activity of guidance to the cadres, to convey messages to them, then selected the method in accordance with the characteristics of the target and also the level of its coaching. 
In the application of persuasive communication techniques in the process of guidance to the cadres, there are several techniques used HTI North Sumatra, so that messages delivered can persuade those who are recruited and nurtured. These techniques are:

a. Associate technique. This technique is the technique of presenting a communication message by menumpangkannya on an object or event that is attracting the attention of audiences. This technique is often used HTI in the process of guidance to the cadres. For example Mega Training activities by displaying national trainers Asep Supriatna, basically to build the cadres

b. Integration techniques. This technique is the technique of communicator ability in unifying himself communicatively with the communicant. This means that through verbal and non-verbal words, the communicator describes his or her fate and therefore becomes one with the communicant. In the application of this technique, in the process of cadre-building, the messages conveyed by HTI, never use my word or us, but use our word. This implies that what HTI fought for is not self-interest, but also the interests of society.

c. The technique of reward (pay-off) and punishment (fear arousing). To persuade the cadres. HTI also applies the technique of reward (pay-off) and punishment (fear arousing). The technique is applied by expressing messages that can arouse hope such as messages relating to the virtue or glory that God will provide by applying the Islamic system, in addition to also revealing messages that are scary or illustrate adverse consequences. like the threat of God to those who do not want to use God's laws in this world. In the context of Islam, this is called basy ${ }^{3}$ ran and na ${ }^{3}$ ran which are exciting news and frightening news.

d. The technique of setting (icing). As in the previous explanation, the icing technique is the technique of persuading others by arranging the communication message in such a way that it is pleasant to hear or read and motivated to do as suggested by the message. In the process of cadre development, HTI North Sumatra also applies this arrangement technique, in which the messages conveyed are arranged in accordance with the characteristics of the target and the level of its development 
Communication Technique of Hizbut Tahrir Indonesia (HTI) in the Development of Cadre in North Sumatera

\section{Human Relation Technique.}

In addition, in applying the informative and persuasive communication techniques, in the process of cadre development, HTI North Sumatra also uses the technique of human relationships. This technique is an interpersonal communication technique whose relationship contains psychological elements that are very deep between communicator with communicant.

The application of HTI in applying this technique through several activities such as making personal contacts, conducting interpersonal visits, conducting interpersonal dialogue, as well as through consultation activities or giving advice and solutions personally to the community, as well as to members of the coaching.

Based on the results of the above research also, if analyzed more deeply that in the process of cadre coaching above, there has been a relationship. In the process of coaching, there is a relationship between participants coaching with the musyrif.

In the process of coaching, the participants will continue to interact and communicate in the coaching, when he gained comfort in the process of interaction and communication. He will open more broadly and deeply in the relationship. But if he does not feel comfortable with it, then he will stop the relationship, and he will shut down.

Furthermore, if analyzed through the Symbolic Interaction theory, then the process of guidance done HTI North Sumatra by applying some communication techniques above, is essentially a process of spreading the symbols to the community and the members, both in the form of verbal symbols as well as non-verbal symbols. Then the members will interpret and give meaning to the symbols conveyed by HTI through the process of interaction between them.

If the meaning given HTI is the same as the meaning interpreted by the members, then they want to support HTI in realizing its ideals. However, if the interpretation of cadre members is not the same as the meaning given by HTI, then they will not support HTI. Therefore, the behavior of cadre members is strongly influenced by the meaning that he gives to certain symbols, for example if he gives meaning that the HTI struggle is true, then he will behave in favor of HTI, but if he gives meaning that the HTI struggle is wrong, support it.

Furthermore, with the interaction between HTI and its members, it will develop the self-concept that exists in every individual in society as well as every individual 


\section{Rubino}

HTI members. It is this self-concept that then encourages members of the cadre to behave whether they want to support HTI or not.

\section{CONCLUSION}

The communication techniques applied by Hizbut Tahrir Indonesia (HTI) of North Sumatera in the cadre development activities are: (1) With informative technique, that is by giving information about HTI and the main ideas that developed, to the cadre members both at the level of public recitation, halaqoh general, level of daris, as well as member level. (2) With persuasive techniques, that is by inviting them to support the da'wah HTI, through dialogue activities, discussions, dividing bulletins, magazines, and so forth. (3) By human relations techniques, by giving interpersonal advice to members of the cadre who experienced problems through consultation activities.

\section{BIBILIOGRAPHY}

Ahmad Syafi'i Mufid (Ed). (2011). Perkembangan Paham Keagamaan Transnasional di Indonesia. Jakarta: Badan Litbang dan Diklat Puslitbang Kehidupan Keagamaan Kementerian Agama RI.

Al-Maragi, A. M. (1982). TafsirAl-Maragi, terj. Bahrun Abubakar dkk Semarang: Toha Putra

Effendy, O. U. (2006). Ilmu Komunikasi Teori dan Praktek (Bandung: Remaja Rosdakarya. Liliweri, A. (2011). Komunikasi Serba Ada Serba Makna. Jakarta: Kencana

Syam, N. W. (2011). Psikologi Sebagai Akar Ilmu Komunikasi, Bandung: Simbiosa Rekatama Media. 